\title{
PENERAPAN METODE BERMAIN PERAN DALAM BENTUK DIALOG UNTUK MELATIH KETERAMPILAN BERBICARA BAHASA MANDARIN SISWA KELAS XI SMAN 2 MALANG
}

\author{
Erfan Mokhamad Wijaya \\ Program Magister Pendidikan Bahasa Indonesia \\ Universitas Negeri Malang \\ erfanmowi@gmail.com
}

\begin{abstract}
Abstrak: Penelitian ini bertujuan mendeskripsikan penerapan metode bermain peran dalam bentuk dialog untuk melatih keterampilan berbicara siswa kelas XI SMAN 2 Malang pada mata pelajaran bahasa Mandarin, serta faktor pendukung dan penghambatnya. Penelitian ini menggunakan pendekatan kualitatif dan jenis penelitian deskriptif. Sumber data pada penelitian ini adalah siswa kelas XI LMT bahasa Mandarin semester genap tahun ajaran 2014/2015. Pengumpulan data dilakukan dengan menggunakan teknik observasi, wawancara, dan dokumentasi. Hasil penelitian ini menunjukkan bahwa semua siswa aktif dan antusias dalam mengikuti pembelajaran dengan menggunakan metode bermain peran dalam bentuk dialog. Selain itu, siswa juga berpendapat bahwa metode bermain peran dalam bentuk dialog ini perlu diterapkan pada pembelajaran bahasa Mandarin, khususnya pada pembelajaran keterampilan berbicara. Dari penelitian ini dapat disimpulkan bahwa penerapan metode bermain peran dalam bentuk dialog terbukti dapat digunakan sebagai salah satu metode yang efektif dan menyenangkan untuk pembelajaran berbicara bahasa Mandarin.
\end{abstract}

Kata kunci: bermain peran, dialog, keterampilan berbicara

Abstract: This study aimed at describing the application of role playing method in the form of dialogs to train Mandarin speaking skill of $11^{\text {th }}$ grade students of SMAN 2 Malang on Mandarin subject along with its supporting and hampering factors. This study applied qualitative descriptive approach. Data source in this study was students of $11^{\text {th }}$ grade LMT of Mandarin, event semester of academic year 2014/2015. Data collection was conducted by observation, interview and documentation. The result of the study showed that all students were active and enthusiastic in following the learning process by role playing method in form of dialogs. Besides that, students also argued that role playing method in form of dialog is needed to be implemented in Mandarin subject learning process, especially in speaking skill part. A conclusion can be drawn from this study that role playing method in form of dialog was proven to be one of effective and fun methods to learn how to speak Mandarin.

Keyword: role play, dialog, speaking skill

\section{PENDAHULUAN}

Sejalan dengan perkembangan ilmu pengetahuan dan teknologi, seseorang dituntut untuk mempunyai keterampilan berbahasa yang baik. Seseorang yang mempunyai keterampilan berbahasa yang baik akan lebih mudah menyerap dan menyampaikan informasi baik secara lisan 
maupun tulisan. Untuk menguasai keterampilan berbahasa yang baik, seseorang diharuskan menguasai empat aspek, yaitu (1) keterampilan menyimak atau mendengarkan, (2) keterampilan berbicara, (3) keterampilan menulis, dan (4) keterampilan membaca.

Salah satu dari empat aspek keterampilan berbahasa yang harus dikuasai oleh seorang pelajar adalah keterampilan berbicara, sebab keterampilan berbicara menunjang keterampilan lainnya (Tarigan, 1986: 86). Keterampilan berbicara harus dikuasai oleh seorang siswa karena keterampilan ini secara langsung berkaitan dengan seluruh proses belajar mengajar. Keberhasilan belajar seorang siswa dalam mengikuti proses kegiatan belajar mengajar di sekolah sangat ditentukan oleh penguasaan keterampilan berbicara mereka. Seorang siswa yang tidak terampil berbicara dengan baik dan benar akan mengalami kesulitan dalam mengikuti kegiatan pembelajaran untuk semua mata pelajaran.

Dalam pembelajaran bahasa asing terutama bahasa Mandarin, keterampilan berbicara adalah komponen terpenting dalam tujuan pembelajaran. Untuk bisa berbicara menggunakan bahasa Mandarin, dibutuhkan latihan ekstra dengan menggunakan bahasa tersebut dengan baik dan benar. Keterampilan berbicara bahasa Mandarin perlu diajarkan khususnya di Sekolah Menengah Atas (SMA), karena dengan keterampilan tersebut seorang pembelajar akan mampu mengembangkan kemampuan berpikir, menyimak, membaca, dan menulis. Biasanya seorang siswa bisa berkomunikasi dalam situasi tidak resmi atau di luar sekolah, tetapi ketika mereka diminta berbicara di depan kelas akan mengalami penurunan kelancaran berkomunikasi. Ada sejumlah siswa yang masih merasa takut dan kurang percaya diri berbicara menggunakan bahasa Mandarin di depan kelas. Sebagaimana yang diungkapkan oleh Supriyadi (2005: 179) bahwa siswa yang belum lancar berbicara tersebut dapat disertai dengan sikap siswa yang pasif, malas berbicara (ogah-ogahan), sehingga siswa merasa takut salah dan malu, atau bahkan kurang berminat untuk berlatih berbicara di depan kelas. Tidak heran, bila masih banyak siswa yang belum bisa berbicara menggunakan bahasa Mandarin dengan lancar serta baik dan benar. Kesulitan untuk berbicara dengan menggunakan bahasa Mandarin dengan lancar serta baik dan benar tersebut juga dialami oleh siswa kelas XI LMT di SMAN 2 Malang.

Berdasarkan hasil observasi di kelas XI LMT SMAN 2 Malang, diketahui bahwa keterampilan berbicara bahasa Mandarin siswa kelas XI LMT SMAN 2 Malang masih rendah. Siswa beranggapan bahwa berbicara bahasa Mandarin merupakan pelajaran yang sulit, sehingga penguasaan materi di kelas XI LMT SMAN 2 Malang terhadap materi pelajaran berbicara bahasa Mandarin masih kurang. Sebagian besar siswa mengalami kesulitan disebabkan kurangnya latihan berbicara dalam pembelajaran bahasa Mandarin, serta pemahaman siswa terhadap materi masih rendah. Hal ini disebabkan keterbatasan media dan metode pembelajaran. Akibatnya, banyak dari mereka yang belum berani dan tidak percaya diri berbicara menggunakan bahasa Mandarin. Ini terbukti ketika guru mengajak berkomunikasi menggunakan bahasa Mandarin, banyak dari mereka yang masih malu dan kurang percaya diri dalam menanggapi materi yang dijelaskan oleh guru.

Sebagai salah satu solusinya, seorang guru dituntut kemampuannya untuk menggunakan metode pembelajaran secara tepat. Salah satu metode yang dapat diterapkan secara tepat untuk melatih keterampilan berbicara bahasa Mandarin, serta dapat menciptakan suasana belajar yang sangat menyenangkan adalah dengan menggunakan metode bermain peran dalam bentuk dialog.

Penggunaan metode bermain peran dalam bentuk dialog sebagai metode pembelajaran keterampilan berbicara perlu dilakukan. Adapun alasan pemilihan menggunakan metode bermain peran dalam bentuk dialog adalah dengan 
pertimbangan bahwa metode ini dapat membuat pembelajaran keterampilan berbicara bahasa Mandarin lebih efektif dan menyenangkan. Metode bermain peran dalam bentuk dialog dikatakan lebih efektif karena siswa tampil praktik berbicara secara berkelompok. Selain itu, siswa dapat menghilangkan perasaan malu dan lebih percaya diri karena mereka tampil dan bekerja sama dengan anggota kelompoknya.

Malik (2005: 68) menyatakan bahwa dalam metode bermain peran peserta diminta untuk melakukan peran tertentu dan menyajikan "permainan peran" dan melakukan "dialogdialog" tertentu yang menekankan pada karakter, sifat atau sikap yang perlu dianalisa. Bermain peran haruslah mengungkapkan suatu masalah atau kondisi nyata yang akan dipergunakan bahan diskusi atau pembahasan materi tertentu. Setelah selesai melakukan peran, langkah berikut adalah analisis dari bermain peran tersebut. Para pemain diminta untuk mengemukakan perasaan mereka tentang peran yang dimainkan, demikian pula dengan peserta lain. Dari pendapat tersebut dapat disimpulkan bahwa metode bermain peran merupakan salah satu metode pembelajaran yakni peserta didik melakukan kegiatan memainkan peran dan melakukan dialog-dialog berdasarkan suatu kasus yang dibahas sebagai materi pembelajaran.

\section{METODE}

Penelitian ini menggunakan pendekatan kualitatif. Menurut pendapat Moleong (2011: 4), penelitian kualitatif merupakan penelitian yang menghasilkan data deskriptif berupa kata-kata tertulis atau lisan dari orang-orang dan perilaku yang dapat diamati. Peneliti mengumpulkan data dan informasi yang selengkap mungkin mengenai penerapan metode bermain peran dalam bentuk dialog untuk melatih keterampilan berbicara siswa kelas XI SMAN 2 Malang pada mata pelajaran bahasa Mandarin.

Jenis penelitiannya merupakan penelitian deskriptif, yaitu penelitian yang bersifat alamiah, yang menggambarkan setiap kejadian yang terjadi pada saat setiap tahapan penelitian berlangsung (Arikunto, 2010: 3). Pada penelitian ini peneliti mendeskripsikan semua kejadian yang terjadi secara alami yang terjadi pada saat proses pembelajaran menggunakan metode bermain peran dalam bentuk dialog.

Kehadiran peneliti dalam penelitian ini menjadi pengamat partisipan, di samping sebagai pengamat peneliti juga berperan sebagai partisipan yang berfungsi sebagai pengumpul data. Peneliti berkeinginan untuk memecahkan masalah yang dihadapi oleh siswa pada kelas lintas minat bahasa Mandarin. Agar peneliti mendapat kepercayaan dari informan dan subjek penelitian, maka peneliti memberitahukan identitas atau status peneliti kepada perangkat sekolah di SMAN 2 Malang.

Penelitian ini dilaksanakan di SMA Negeri 2 Malang yang terletak di jalan Laksamana Laut RE Martadinata nomor 84, Malang, Jawa Timur, Indonesia dengan kepala sekolah yang dijabat oleh ibu Dr. Rr. Dwi Retno Undjian Ningsih, M.Pd. Penelitian ini dilaksanakan di kelas XI lintas minat bahasa Mandarin. Pemilihan SMA Negeri 2 Malang sebagai lokasi penelitian adalah berdasarkan beberapa pertimbangan sebagai berikut.

1. Sekolah tersebut mengizinkan untuk dilaksanakan kegiatan penelitian dengan tujuan meningkatkan kualitas pembelajaran bahasa Mandarin di SMAN 2 Malang.

2. Sekolah bersedia memberikan data yang diperlukan peneliti.

3. Keterampilan berbicara bahasa Mandarin di sekolah tersebut masih rendah.

Di sekolah tersebut pembelajaran bahasa Mandarin belum pernah digunakan sebagai objek penelitian. Penelitian ini diharapkan mampu memberikan manfaat besar bagi sekolah tersebut.

Sumber data dalam penelitian ini adalah 11 orang siswa kelas XI LMT SMAN 2 Malang semester genap tahun ajaran 2014/2015 yang mengikuti pembelajaran bahasa Mandarin. 
Data berupa catatan-catatan atau observasi yang diperoleh selama proses pembelajaran dengan metode bermain peran dalam bentuk dialog, hasil wawancara dengan guru dan siswa setelah diterapkan metode tersebut serta hasil dokumentasi.

Prosedur pengumpulan data adalah caracara atau langkah-langkah yang digunakan untuk memperoleh data. Dalam penelitian ini, data yang dikumpulkan berupa penerapan metode bermain peran dalam bentuk dialog untuk melatih keterampilan berbicara bahasa Mandarin siswa kelas XI SMAN 2 Malang. Pengumpulan data dilaksanakan dengan 3 teknik, yaitu observasi, wawancara, dan dokumentasi.

Observasi adalah suatu proses yang komplek yang disengaja dan dilakukan secara sistematis, terencana, terarah, pada suatu tujuan dengan mengamati dan mencakup fenomena satu atau sekelompok orang dalam kehidupan sehari-hari untuk mendapatkan informasi yang dibutuhkan. Observasi digunakan sebagai salah satu cara pengumpulan data apabila penelitian yang dilakukan berhubungan dengan perilaku manusia, proses kerja, dan responden yang diamati jumlahnya tidak terlalu besar (Sugiyono, 2015: 203). Kegiatan observasi ini dilakukan untuk melihat aktivitas siswa selama proses pembelajaran dengan metode bermain peran dalam bentuk dialog.

Kegiatan observasi ini dimaksudkan untuk memperoleh data nyata di lapangan dan dilakukan pengamatan langsung terhadap objek yang diteliti dengan menggunakan lembar pedoman observasi. Langkah-langkah yang dilakukan peneliti adalah:

1. Menentukan tujuan pembuatan lembar observasi, yaitu untuk merekam data berapa banyak siswa di kelas aktif belajar dan bagaimana kualitas aktivitas belajar siswasiswa tersebut.

2. Menyusun pernyataan-pernyataan dalam lembar observasi yang akan digunakan dalam proses penelitian.

3. Mengisi pernyataan-pernyataan sesuai dengan keadaan yang ada di dalam kelas.
Wawancara adalah percakapan dengan maksud tertentu. Percakapan ini dilakukan oleh dua pihak, yaitu pewawancara yang mengajukan pertanyaan dan yang diwawancarai memberikan jawaban atas pertanyaan itu (Moleong, 2011: 186). Menurut Sugiyono (2015: 317), wawancara digunakan sebagai teknik pengumpulan data apabila peneliti ingin melakukan studi pendahuluan untuk menemukan permasalahan yang harus diteliti, tetapi juga apabila peneliti ingin mengetahui hal-hal dari responden yang lebih mendalam. Teknik pengumpulan data ini mendasarkan diri pada laporan tentang diri sendiri atau self-report, atau setidak-tidaknya pada pengetahuan dan atau keyakinan pribadi. Peneliti menggunakan wawancara dengan tujuan untuk memperoleh data yang berkaitan dengan proses pelaksanaan penerapan metode bermain peran dalam bentuk dialog. Adapun sumber informasi (informan) adalah Ibu Ismi Rahayu selaku guru bahasa Mandarin SMA Negeri 2 Malang dan beberapa siswa SMA Negeri 2 Malang (Ghea, Hurul, Yovita, Yuniar, Dhisti, Axnes, Cisilia, Ilham, Putri).

Dokumentasi yang dilakukan dalam proses pembelajaran dengan metode bermain peran dalam bentuk dialog adalah hasil foto dan rekaman video siswa selama proses pembelajaran pada saat penelitian tersebut berlangsung. Dengan menggunakan dokumentasi dapat diperoleh data secara nyata bahwa metode tersebut dijalankan. Langkah-langkah yang dilakukan peneliti adalah: 1. Mendokumentasikan kegiatan pembelajaran yang dilakukan dengan menerapkan metode bermain peran dalam bentuk dialog.

2. Mendeskripsikan hasil dokumentasi berupa foto-foto dan video rekaman siswa selama proses pembelajaran dengan menerapkan metode bermain peran dalam bentuk dialog tersebut berlangsung.

Penelitian ini merupakan penelitian deskripif yang memberikan gambaran atau uraian atas keadaan yang diamati secara jelas tanpa ada perlakuan terhadap objek yang diteliti. Sugiyono (2015: 334) menyatakan bahwa analisis 
data adalah proses mencari dan menyusun secara sistematis data yang diperoleh dari hasil wawancara, catatan lapangan, dan bahan-bahan lain sehingga mudah dipahami, dan temuannya dapat diinformasikan kepada orang lain. Oleh sebab itu, peneliti menguraikan tahapan-tahapan penelitian deskriptif kualitatif sebagai berikut.

1. Mengecek kelengkapan data

2. Mengecek isian data

3. Mengolah data (dapat dilihat dari hasil observasi, hasil wawancara, foto, dan rekaman video siswa)

4. Menyimpulkan semua penelitian yang telah dilaksanakan.

Kriteria keabsahan data yang digunakan dalam penelitian penerapan metode bermain peran dalam bentuk dialog adalah kriteria derajat kepercayaan (credibility). Derajat kepercayaan yang digunakan dalam penelitian ini adalah triangulasi. Sugiyono (2015: 373) menjelaskan bahwa triangulasi merupakan cara yang digunakan untuk mengecek data dengan menggabungkan berbagai teknik pengumpulan data dan sumber data yang sudah ada. Dalam penelitian ini, dilakukan tringulasi sumber, yaitu pengecekan data yang dilakukan dari beberapa sumber yang telah diperoleh, yaitu dalam hasil observasi, wawancara, dan dokumentasi. Berdasarkan triangulasi sumber tersebut, peneliti melakukan pengecekan data yang diperoleh dari observasi, wawancara dan dokumentasi. Pengecekan keabsahan data pada penelitian ini didampingi oleh Ibu Ismi Rahayu, S.Pd. selaku guru ahli bahasa Mandarin SMAN 2 Malang dan dikonsultasikan dengan Bapak Dr. Rizman, M.Pd. dan Ibu Dra. Rosyidah, M.Pd. selaku dosen pembimbing jurusan Sastra Jerman Universitas Negeri Malang.

Tahap-tahap penelitian pada penelitian ini adalah:

\section{Persiapan penelitian}

Persiapan penelitian yang dilakukan oleh peneliti sebelum menggunakan metode bermain peran dalam bentuk dialog adalah sebagai berikut. a. Refleksi awal antara guru dan peneliti secara kolaboratif untuk mengidentifikasikan permasalahan pada proses pembelajaran.

b. Peneliti dan guru merancang pelaksanaan pemecahan masalah dengan menerapkan metode bermain peran dalam bentuk dialog.

c. Menyusun perangkat pembelajaran yang terdiri dari RPP dan media pembelajaran.

d. Menyusun alat perekam data yang berupa lembar observasi, perekam suara untuk wawancara serta kamera untuk merekam saat penelitian berlangsung.

\section{Pelaksanaan}

Dalam pelaksanaan peneliti bertindak sebagai pengamat saat guru ahli menerapkan metode bermain peran dalam bentuk dialog. Sesuai dengan RPP yang telah dibuat, terdapat tiga tahapan dalam pembelajaran, yaitu pendahuluan, kegiatan inti, dan penutup. Pada pendahuluan, guru memberikan materi singkat tentang tema 日常生活 (richang shenghuo/ kehidupan sehari-hari). Selanjutnya pada kegiatan inti, guru menerapkan metode bermain peran dalam bentuk dialog dengan menggunakan tema tersebut dalam pembelajaran untuk mengetahui keterampilan berbicara siswa. Pada kegiatan penutup, guru membimbing siswa untuk menyimpulkan pembelajaran setelah diterapkannya metode bermain peran dalam bentuk dialog.

\section{HASIL DAN PEMBAHASAN}

\section{Penerapan Metode Bermain Peran dalam Bentuk Dialog}

Penerapan metode bermain peran dalam bentuk dialog menuntut keaktifan dan partisipasi siswa dalam kegiatan belajar mengajar seoptimal mungkin, sehingga siswa mampu mengubah tingkah laku secara efektif dan efisien dalam kehidupan sehari-hari. Hal ini sesuai dengan pendapat Anas (2014: 52) yang mengungkapkan, bahwa penggunaan metode bermain peran harus disesuaikan dengan tujuan pembelajaran, agar tujuan dapat tercapai secara efektif dan efisien.

Secara umum, pelaksanaan penerapan metode bermain peran dalam bentuk dialog 
untuk melatih keterampilan berbicara siswa kelas XI SMA Negeri 2 Malang pada mata pelajaran bahasa Mandarin. Hal ini berjalan lancar dan mengikuti langkah-langkah yang ada dalam rencana pelaksanaan pembelajaran yang sebelumnya sudah dipersiapkan oleh guru dan peneliti. Langkah-langkah yang dimulai dengan kegiatan awal, kegiatan inti, dan kegiatan penutup terlaksana dengan sangat baik dan lancar.

Dalam penerapan metode bermain peran dalam bentuk dialog, guru mendesain pembelajaran dengan membagi siswa ke dalam kelompok-kelompok yang telah ditetapkan. Setiap kelompok terdiri dari 2 sampai 3 orang siswa. Masing-masing anggota kelompok mendapatkan dialog tentang 日常生活 (richang shenghuo/ kehidupan sehari-hari). Selanjutnya, masingmasing kelompok bersiap-siap menerapkan metode bermain peran dalam bentuk dialog. Kemudian guru mempersilahkan kepada setiap kelompok untuk berdiskusi dan latihan bermain peran dalam bentuk dialog. Setelah diskusi dan latihan bermain peran dalam bentuk dialog selesai dilakukan, guru secara acak meminta beberapa kelompok untuk menampilkan hasil diskusi dan latihan mereka untuk bermain peran dalam bentuk dialog di depan kelas. Sama halnya dengan pendapat Malik (2005: 63) yang mengungkapkan, bahwa metode bermain peran melibatkan seluruh peserta dalam kelas untuk memainkan peran masing-masing yang telah ditentukan oleh pemandu.

Selama proses pembelajaran berlangsung, siswa terlihat sangat bersemangat dan antusias. Hal ini dapat dilihat dari hasil observasi dan wawancara yang menyatakan bahwa pembelajaran dengan penerapan metode bermain peran dalam bentuk dialog mampu menarik minat dan perhatian siswa terhadap materi yang disampaikan oleh guru.

Berdasarkan hasil observasi, dapat disimpulkan bahwa siswa antusias dalam bermain peran dalam bentuk dialog, aktif, dan sudah mulai percaya diri dalam berbicara menggunakan bahasa Mandarin, meskipun masih terdapat beberapa kesalahan dalam pelafalannya, serta tidak segan-segan untuk bertanya kepada guru ketika mengalami kesulitan dalam memahami materi 日常生活 (richang shenghuo/ kehidupan sehari-hari). Siswa juga bekerja sama dengan baik di dalam kelompok dan mampu bermain peran dengan baik.

Berdasarkan hasil wawancara diperoleh bahwa siswa tertarik, antusias, dan bersemangat dalam mengikuti proses belajar mengajar dengan materi åe ${ }^{\wedge} u ; m$ (richang shenghuo/kehidupan sehari-hari) dengan menggunakan metode bermain peran dalam bentuk dialog. Hal ini disebabkan oleh metode bermain peran dalam bentuk dialog yang menarik dan menyenangkan, sehingga memotivasi siswa untuk lebih giat dalam belajar bahasa Mandarin dan memudahkan siswa dalam memahami materi 日常生活 (richang shenghuo/kehidupan sehari-hari), serta lebih aktif berbicara bahasa Mandarin di kelas. Semua siswa juga berpendapat bahwa metode bermain peran dalam bentuk dialog sangat tepat untuk diterapkan pada pembelajaran keterampilan berbicara bahasa Mandarin.

Dalam kegiatan belajar mengajar, siswa dituntut untuk aktif agar siswa mempunyai pemahaman yang lebih tentang materi yang diajarkan serta hasil belajar siswa diharapkan meningkat. Dari pelaksanaan pembelajaran penerapan metode bermain peran dalam bentuk dialog, diperoleh hasil berupa nilai keterampilan berbicara siswa kelas XI SMA Negeri 2 Malang pada mata pelajaran bahasa Mandarin. Hal-hal yang dinilai oleh guru adalah pelafalan, ketepatan kosakata, intonasi, mimik wajah, dan gerak tubuh.

Nilai keterampilan berbicara siswa kelas XI SMA Negeri 2 Malang sangat memuaskan. Hal ini terbukti dari data tabel hasil belajar siswa, dapat diketahui bahwa sebanyak 4 siswa memperoleh nilai 100 , selanjutnya sebanyak 2 siswa memperoleh nilai 95, kemudian 2 siswa memperoleh nilai 90, dan yang terakhir 1 siswa memperoleh nilai 85 . Berdasarkan hasil penilaian yang sudah diperoleh tersebut, dapat disimpulkan bahwa $100 \%$ siswa sudah mampu mencapai

KEMBARA: Jurnal Keilmuan Bahasa, Sastra, dan Pengajarannya, Volume 3, Nomor 1, April 2017, hlm 41-48 
Kriteria Ketuntasan Minimal (KKM) yang ditetapkan di SMA Negeri 2 Malang, yaitu 75.

Melalui penerapan metode bermain peran dalam bentuk dialog selain siswa menjadi lebih aktif, bersemangat, dan antusias dalam mengikuti pembelajaran, metode ini juga dapat meningkatkan hasil belajar siswa, karena siswa secara langsung melakukan praktik berbicara dalam bahasa Mandarin. Demikian pula halnya dengan Zuhaerini (1983: 56) yang mengungkapkan, bahwa dalam metode bermain peran, siswa diperlakukan sebagai subjek pembelajaran, secara aktif melakukan praktikpraktik berbahasa bersama teman-temannya pada situasi tertentu. Belajar efektif dimulai dari lingkungan yang berpusat pada diri murid. Oleh karena itu, metode pembelajaran sangat penting untuk digunakan di dalam proses pembelajaran.

\section{Faktor Pendukung Penerapan Metode Bermain Peran dalam Bentuk Dialog}

Faktor pendukung dalam penerapan metode bermain peran dalam bentuk dialog untuk melatih keterampilan berbicara siswa kelas XI SMA Negeri 2 Malang pada mata pelajaran bahasa Mandarin adalah:

1. Penggunaan materi yang sederhana dan teks dialog yang mudah dipahami oleh siswa

2. Petunjuk yang diberikan guru jelas

3. Adanya tuntutan siswa untuk aktif berbicara

4. Adanya kerjasama dalam kelompok

5. Adanya semangat siswa dalam belajar bahasa Mandarin

Dengan adanya beberapa faktor pendukung tersebut di atas, dapat disimpulkan bahwa metode bermain peran dalam bentuk dialog ini memang perlu diterapkan untuk pembelajaran bahasa Mandarin, khususnya untuk keterampilan berbicara siswa. Penerapan metode bermain peran dalam bentuk dialog ini merupakan metode yang menyenangkan. Dengan menerapkan metode tersebut, siswa menjadi termotivasi, bersemangat dan dapat meningkatkan pemahaman mereka tentang materi yang dipelajari. Hal ini sesuai dengan pendapat Anas (2014: 52) yang mengungkapkan bahwa metode bermain peran dapat memberikan siswa kesenangan dan suasana yang menggembirakan. Selama mereka belajar dengan metode bermain peran dapat meningkatkan pemahaman siswa terhadap materi pelajaran.

\section{Faktor Penghambat Penerapan Metode Bermain Peran dalam Bentuk Dialog}

Dalam penerapan metode bermain peran dalam bentuk dialog untuk melatih keterampilan berbicara siswa kelas XI SMA Negeri 2 Malang pada mata pelajaran bahasa Mandarin ada dua faktor yang menghambat penerapan metode tersebut, yaitu efisiensi waktu dan siswa masih merasa malu-malu, serta tidak percaya diri tampil di depan kelas. Penerapan metode bermain peran dalam bentuk dialog memang membutuhkan banyak waktu. Penggunaan waktu yang banyak sesuai dengan pendapat Anas (2014: 53) yang mengungkapkan, bahwa membutuhkan banyak waktu untuk melakukan persiapan dalam bermain peran dan dibutuhkan kecakapan bahasa yang baik dari siswa. Siswa yang masih malu-malu dan tidak percaya diri juga membutuhkan latihan lebih banyak bersama kelompok agar dapat tampil sempurna di depan kelas.

\section{Pembahasan}

Dalam pelaksnaan proses pembelajaran menggunakan metode bermain peran dalam bentuk dialog telah memberikan kemudahan kepada siswa. Hal ini ditunjukkan dengan siswa yang aktif dan antusias dalam mengikuti pembelajaran. Selain itu, dengan menggunakan metode ini siswa dapat langsung melakukan praktik berbicara bahasa Mandarin, sehingga dapat langsung mengaplikasiannya. Dengan demikian, perlu langkah nyata untuk menindak lanjuti beberapa faktor yang sudah diulas di bagain hasil untuk mendapatkan pembelajaran yang menyenangkan. 


\section{KESIMPULAN}

Metode bermain peran dalam bentuk dialog merupakan salah satu metode pembelajaran yang efektif diterapkan pada pembelajaran keterampilan berbicara di SMA Negeri 2 Malang. Dari hasil penelitian yang telah dilakukan, pembelajaran dengan menerapkan metode ini terbukti mampu membuat siswa bersemangat dan aktif dalam proses pembelajaran, sehingga siswa tidak merasa bosan dalam pembelajaran bahasa Mandarin, khususnya pada keterampilan berbicara.

Penerapan metode bermain peran dalam bentuk dialog ini terbukti mampu menumbuhkan semangat, motivasi, dan dapat meningkatkan hasil belajar siswa dalam pembelajaran bahasa Mandarin. Pada saat proses pembelajaran berlangsung, semua siswa aktif berbicara, diskusi, dan bekerja sama di dalam kelompoknya masing-masing. Siswa yang awalnya malu-malu dan tidak percaya diri dalam berbicara bahasa Mandarin menjadi tidak malu lagi dan sudah mulai percaya diri.

Pembelajaran dengan penerapan metode bermain peran dalam bentuk dialog berjalan dengan lancar dan sesuai dengan Rencana
Pelaksanaan Pembelajaran (RPP) yang telah dipersiapkan guru dan peneliti sebelumnya. Semua siswa terlibat dan berpartisipasi secara aktif selama proses pembelajaran berlangsung. Semua siswa mampu menerapkan metode bermain peran dalam bentuk dialog dengan sangat baik.

\section{DAFTAR PUSTAKA}

Anas, M. (2014). Mengenal Metodologi Pembelajaran. Jakarta: Muhammad Anas. Arikunto, S. (2010). Prosedur Penelitian Suatu Pendekatan Praktik. Jakarta: PT. Rineka Cipta.

Malik, J. (2005). Pemberdayaan Pesantren Menuju Kemandirian dan Profesionalisme Santri dengan Metode Daurah Kebudayaan. Jakarta: Pustaka Pesantren.

Moleong, L. (2011). Metodologi Penelitian Kualitatif. Bandung: PT Remaja Rosdakarya. Sugiyono. (2015). Metode Penelitian dan Pengembangan Research and Development. Bandung: Alfabeta.

Supriyadi, dkk. (2005). Pendidikan Bahasa Indonesia 2. Jakarta: Depdikbud.

Zuhaerini. (1983). Filsafat Pendidikan Islam. Jakarta: Depag. 